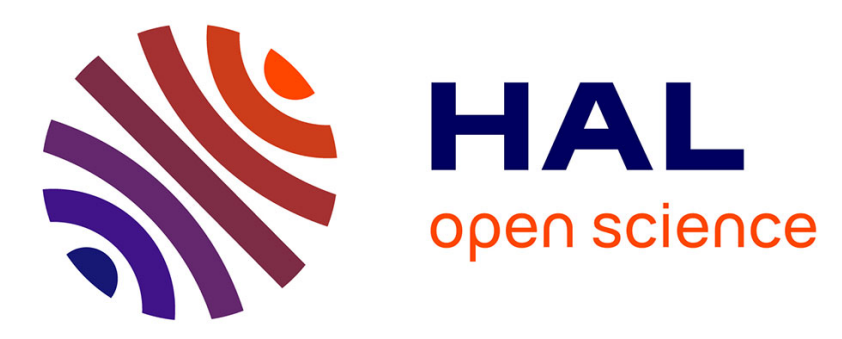

\title{
Tunable optical absorption on "ZnxTixO4-3yN2y" nanosized spinel powders
}

David Berthebaud, Fabien Grasset, Vincent Allegret-Maret, Soraya Ababou-Girard, Stanislav Pechev

\section{- To cite this version:}

David Berthebaud, Fabien Grasset, Vincent Allegret-Maret, Soraya Ababou-Girard, Stanislav Pechev. Tunable optical absorption on "ZnxTixO4-3yN2y" nanosized spinel powders. Journal of Physical Chemistry C, 2007, 111 (22), pp.7883-7888. 10.1021/jp0716334 . hal-00154371

\section{HAL Id: hal-00154371 https://hal.science/hal-00154371}

Submitted on 21 Oct 2021

HAL is a multi-disciplinary open access archive for the deposit and dissemination of scientific research documents, whether they are published or not. The documents may come from teaching and research institutions in France or abroad, or from public or private research centers.
L'archive ouverte pluridisciplinaire HAL, est destinée au dépôt et à la diffusion de documents scientifiques de niveau recherche, publiés ou non, émanant des établissements d'enseignement et de recherche français ou étrangers, des laboratoires publics ou privés. 


\title{
Tunable Optical Absorption on " $\mathrm{Zn}_{x} \mathrm{Ti}_{x} \mathrm{O}_{4-3 y} \mathrm{~N}_{2 y}$ ” Nanosized Spinel Powders
}

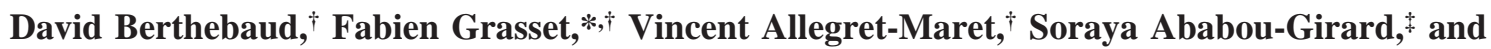 \\ Stanislav Pechev ${ }^{\S}$
}

Science Chimiques de Rennes, UMR 6226 CNRS-Université de Rennes 1, Campus de Beaulieu, CS74205, F-35042 Rennes Cedex, France, PALMS, UMR CNRS-UR1 6627, Université de Rennes 1,

Campus de Beaulieu, 35042 Rennes Cedex, France, and Institut de Chimie de la Matière Condensée de Bordeaux, UPR CNRS 9048, Université Bordeaux-1, 87 Avenue du Dr Albert Schweitzer, F-33608 Pessac Cedex, France

Received: February 28, 2007; In Final Form: March 29, 2007

Using a recently developed sol-gel route to prepare new $\mathrm{Ti}^{4+} @ \mathrm{ZnO}$ nanocolloids, we were able to synthesize, at relatively low temperature (maximum $750{ }^{\circ} \mathrm{C}$ ) and very short annealing time $(1 \mathrm{~h}$ ) under ammonia gas flow, nanosized colored " $\mathrm{Zn}_{1.33} \mathrm{Ti}_{1.33} \mathrm{O}_{4-3 y} \mathrm{~N}_{2 y}$ " oxynitride powders $(\mathrm{Zn} / \mathrm{Ti}=1)$ with tunable optical absorption. Above the dissociation temperature of ammonia, the UV-vis spectra are progressively red-shifted with increasing nitriding temperature and the nanosized powder shows a yellowish color at $700{ }^{\circ} \mathrm{C}$ under $\mathrm{NH}_{3}$. $\mathrm{X}$-ray diffraction, scanning electron microscopy, X-ray photoemission spectroscopy, oxygen and nitrogen analysis, and UV-vis spectroscopy measurements show that this red shift is directly related to the nitrogen content.

\section{Introduction}

Nanomaterials represent a new class of materials with continuously increasing fields of application-environment, catalysis, biotechnology, and magnetic and optical devices. Particularly, nanoparticles have generated a large research effort in the past 10 years because their properties differ markedly from those of their bulk counterpart. ${ }^{1}$ Recently, we developed a new low-cost colloidal sol-gel route to prepare nanosized colored "ZnTiON", $1 \mu \mathrm{m}$ thick, porous layers on glass. ${ }^{2}$ First, we had prepared highly concentrated $\mathrm{ZnO}$ nanocolloids using an alcoholic clusters route developed in refs 3 and 4 . Then we added titanium tetraisopropoxide in order to obtain new $\mathrm{Ti}^{4+} @ \mathrm{ZnO}$ nanocolloids. To get colored oxynitrides, we used an ammonia-induced replacement of oxygen by nitrogen according to the general equation oxide $+\mathrm{NH}_{3} \rightarrow$ oxynitrides + $\mathrm{H}_{2} \mathrm{O}$, well-known from classical solid-state chemistry. ${ }^{5}$ These kinds of colored porous thin films showed excellent photostability and photodegradation of an aqueous methylene blue solution in the visible spectrum. ${ }^{2,6}$ These results corroborate recent works about oxynitrides or nitrogen-doped oxides reporting high photocatalytic activity under visible light (refs 7 and 8 and references therein). In this paper, we present the microstructural characterization of "ZnTiON" nanosized powders obtained from nanocolloids. The nanosized powders were studied by X-ray diffraction (XRD), scanning electron microscopy (SEM), X-ray photoemission spectroscopy (XPS), oxygen and nitrogen analysis, and UV-vis spectroscopy.

\section{Experimental Section}

Synthesis Process. The nanosized powders were synthesized from $\mathrm{Ti}^{4+} @ \mathrm{ZnO}$ nanocolloids by evaporation of alcohol using a rotating evaporator. Briefly, $\mathrm{Ti}^{4+} @ \mathrm{ZnO}$ nanocolloids were

* To whom correspondence should be addressed. Telephone: +33223 236 540. Fax: +33223236 799. E-mail: grasset@univ-rennes1.fr.

†UMR 6226 CNRS, Université de Rennes 1.

¥UMR CNRS-UR1 6627, Université de Rennes 1 .

$\S$ Université Bordeaux-1. prepared using zinc acetate dihydrate (4.39 g) suspended in $n$-propanol $(40 \mathrm{~mL})$ under ambient atmosphere and distilled for $10 \mathrm{~min}$ in a preheated silicon oil bath $\left(125^{\circ} \mathrm{C}\right)$. Under magnetic stirring, methanolic tetramethylammonium hydroxide (TMAH) base solution was rapidly added $(9 \mathrm{~mL}, 2.37 \mathrm{M})$ to the still hot precursor $\left(45^{\circ} \mathrm{C}\right)$, yielding initially a turbid precipitate which next turned into a clear nanocolloid after a few minutes. To the fresh sol, we added titanium tetraisopropoxide precursor $(\mathrm{Zn} /$ $\mathrm{Ti}=1$ ), which readily reacts with the ZnO nanocrystals. After cooling to room temperature, the solvant was removed using a rotary evaporator $\left(40{ }^{\circ} \mathrm{C}, 20 \mathrm{~Pa}\right)$. The resulting soft-gel was then kept in an oven at $100{ }^{\circ} \mathrm{C}$ during 1 week in order to solidify, then was ground and pre-sintered at $400{ }^{\circ} \mathrm{C}$ in air to remove the organic residues, and finally transformed into white powder. To get colored oxynitrides, the powders $(0.5 \mathrm{~g})$ are annealed under ammonia gas (purity N36) for $1 \mathrm{~h}$ at temperatures between 550 and $750{ }^{\circ} \mathrm{C}$ and then cooled by removing the electrical power under ammonia flow.

Elemental Analysis. Nitrogen and oxygen contents were determined with a TC-436 analyzer from LECO, Inc. using the inert gas fusion method, nitrogen as $\mathrm{N}_{2}$ by thermal conductivity, and oxygen as $\mathrm{CO}_{2}$ by infrared detection. The apparatus was calibrated with $\mathrm{N}_{2}$ and $\mathrm{CO}_{2}$ gas (purity, 99.95\%). At least three analyses were performed for each sample in the same conditions.

X-ray Intensity Measurements and Peak Profile Analysis. The powder X-ray diffraction data were recorded at diffractometers with Bragg-Brentano geometry, $\mathrm{Cu} \mathrm{K \alpha}$ radiation (40 $\mathrm{kV}, 30 \div 40 \mathrm{~mA}$, and $0.5 \div 10 \mathrm{~s}$ integration time), proportional detectors, and secondary monochromators. At room temperature a Philips PW 3020 was used. The high-temperature XRD experiments were performed on a Philips X'Pert MPD with an Anton Paar HTK-16 camera, where the powder sample is deposed directly on the heating element-a platinum strip.

The average apparent crystallite size $\left(\epsilon_{\beta}\right)$ was evaluated from a whole diffraction pattern profile analysis, using last developments implemented in the Fullprof program (version 2.0 Nov 2001, LLB, Juan Rodriguez-Carvajal). A normalized Voigt 


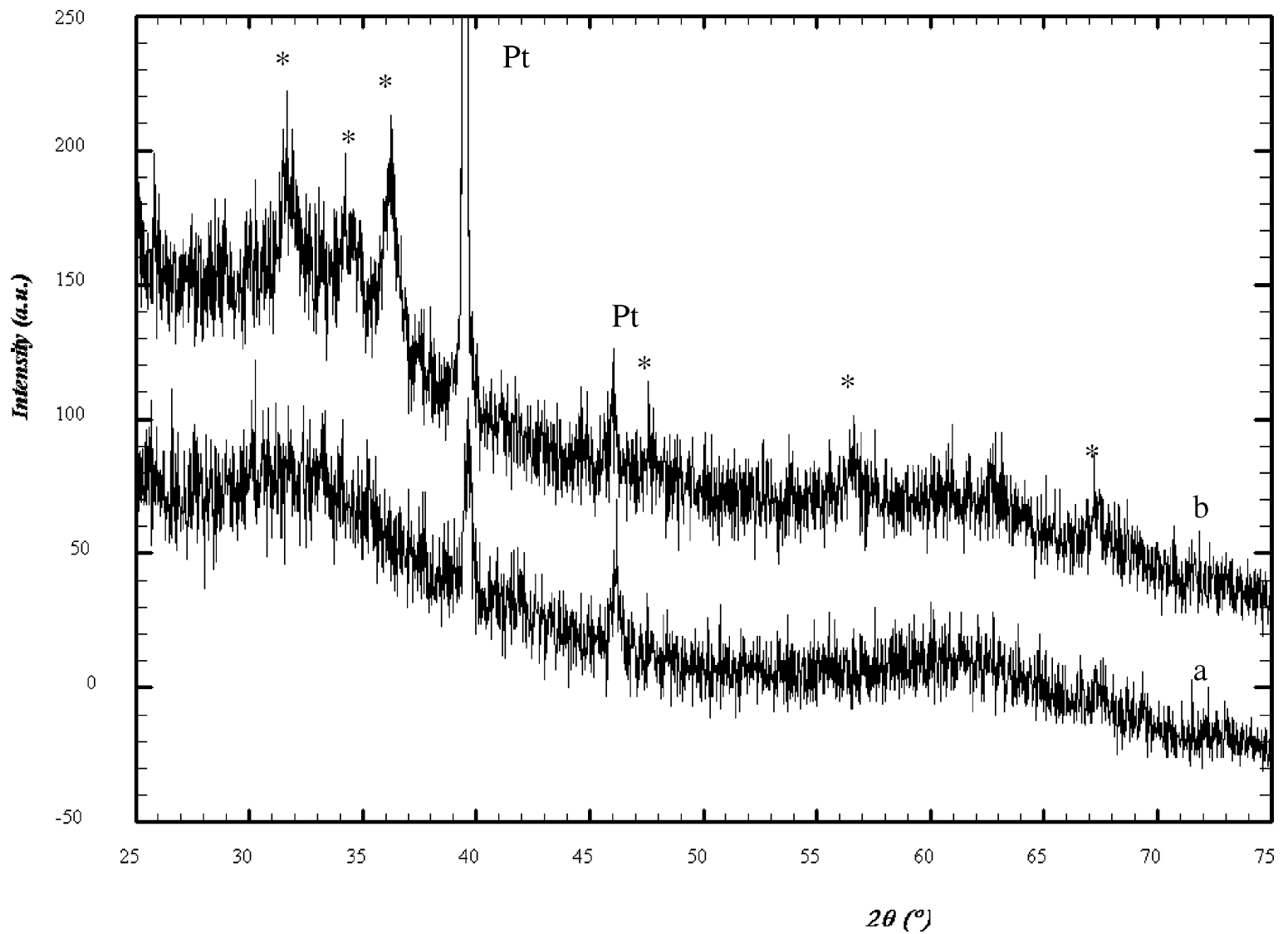

Figure 1. X-ray diffraction at $25^{\circ} \mathrm{C}$ of nanopowders with $\mathrm{Zn} / \mathrm{Ti}=1$ (a) and $\mathrm{Zn} / \mathrm{Ti}=2$ (b) ratios. $(\mathrm{Pt}=$ platinum sample holder; $*=\mathrm{ZnO}$ main peaks.)

function (convolution of Gaussian and Lorentzian functions) was used to fit the peak profiles. The profile analysis is based on the angular dependence of the full width at half-maximum (FWHM) of the Gaussian and Lorentzian components $\left(H_{\mathrm{G}}\right.$ and $H_{\mathrm{L}}$, respectively). Both instrumental and sample intrinsic contributions to the line broadening were examined separately. When the instrumental resolution function (IRF) is known, the sample contribution to the line profile is calculated as follows:

$$
\begin{aligned}
& H_{\mathrm{G}}{ }^{2}=\left(U_{\text {strain iso }}+(1-\xi)^{2} D_{\text {strain aniso }}{ }^{2}\right) \operatorname{tg}^{2} \theta+\frac{G_{\text {size iso }}}{\cos ^{2} \theta} \\
& H_{\mathrm{L}}=\left(X_{\text {strain iso }}+\xi D_{\text {strain aniso }}\right) \operatorname{tg} \theta+\frac{Y_{\text {size iso }}+F_{\text {size aniso }}}{\cos \theta}
\end{aligned}
$$

where $U_{\text {strain iso, }} X_{\text {strain iso }}, G_{\text {size iso, and }} Y_{\text {size iso }}$ are refinable parameters related to isotropic size and strain effects on the line broadening, while $D_{\text {strain aniso }}$ and $F_{\text {size aniso }}$ are analytical functions for an $h k l$-dependent broadening model. $\xi$ is a mixing coefficient for the Lorentzian part of the strains. The integral-breadth method is applied, finally, to determine the crystallite size and strains in the sample. "Perfect" $\mathrm{Y}_{2} \mathrm{O}_{3}$ powder was used as a standard to determine the resolution function of the diffractometer. The observed line broadening was modeled by considering isotropic size and strain contributions. Only the size-related terms of $H_{\mathrm{G}}$ and $H_{\mathrm{L}}\left(G_{\text {size iso }}\right.$ and $\left.Y_{\text {size iso }}\right)$ converged to significant values. The strain-dependent parameters ( $U_{\text {strain iso }}$ and $\left.X_{\text {strain iso }}\right)$ had meaningless values, which did not influence the profile fitting of the XRD patterns. After the profile refinement, the apparent size along each reciprocal lattice vector is calculated. The average apparent crystallite size $\left(\epsilon_{\beta}\right)$ can be related to the true size, but only if the crystallite shape is known or assumed. For instance, for a spherical crystallite, the true diameter $D$ is simply given by $4 / 3\left(\epsilon_{\beta}\right)$. Moreover, this simple relation is strictly valid for a monodisperse system. ${ }^{9}$ So, the true size could be defined only in the case of single-domain nanoparticles without amorphous shell, as it is for transmission electron microscopy (TEM) and/or scanning electron microscopy (SEM) images.

Morphological Investigations by SEM. SEM photographs were taken by JEOL JSM 6301F microscope to examine the shape and size of the nanoparticles.

UV-Vis Spectroscopy. Diffuse reflectance spectra were collected using a UV-vis CARY 100 spectrometer equipped with a Labsphere DRA-CA-30I with a $70 \mathrm{~mm}$ diameter coated with Spectralon (PTFE). The absolute reflectance of the sample is compared with a calibrated 2 in. D 99\% Spectralon reflectance standard.

X-ray Photoemission Spectroscopy. XPS was performed under a base pressure of $5 \times 10^{-9}$ mbar using a VSW HA100 spectrometer. The analyzer was operated with at constant pass energy of $22 \mathrm{eV}$, which leads to an experimental resolution of $1.1 \mathrm{eV}$. The X-ray source used either $\mathrm{Al}$ or $\mathrm{Mg} \mathrm{K} \alpha$ excitation radiation at 1486.6 and $1283.6 \mathrm{eV}$, respectively. The spectrometer binding energy scale was initially calibrated against the $\mathrm{Au} 4 \mathrm{f} 7 / 2$ (84.0 eV) level and $\mathrm{Cu}$ 2p3/2 (932.7 eV). Since the films were nonconductive, they were referenced to adventitious hydrocarbon with $\mathrm{C} 1 \mathrm{~s}$ binding energy at $284.9 \mathrm{eV}$

\section{Results and Discussion}

Using the described soft method to synthesize $\mathrm{ZnO}$ nanocolloids, the hydrodynamic diameter of the $\mathrm{ZnO}$ nanoparticles is around $7 \mathrm{~nm} .{ }^{10}$ Nevertheless, analysis of the X-ray powder 


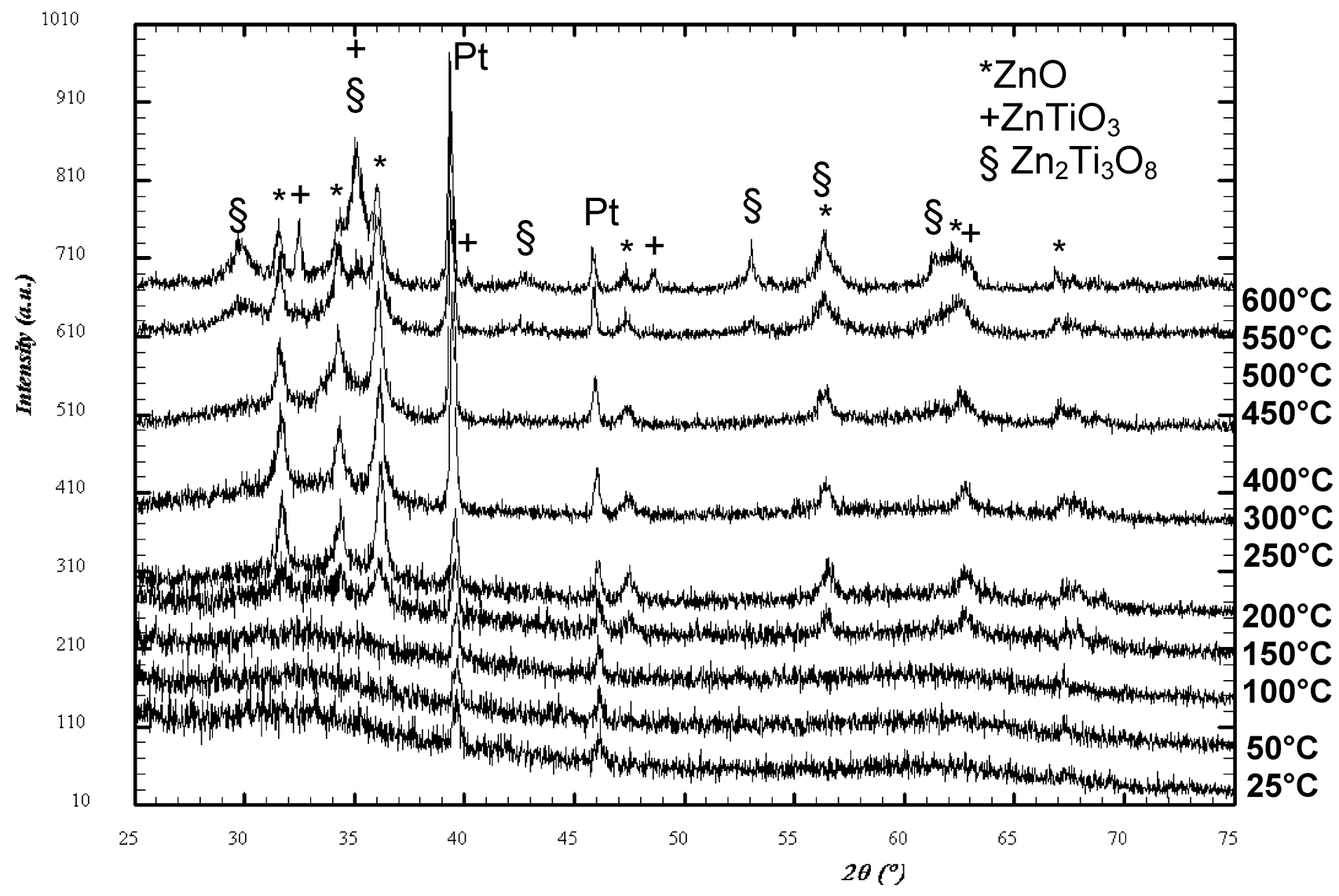

Figure 2. Temperature-dependent $\mathrm{X}$-ray diffraction under air atmosphere.

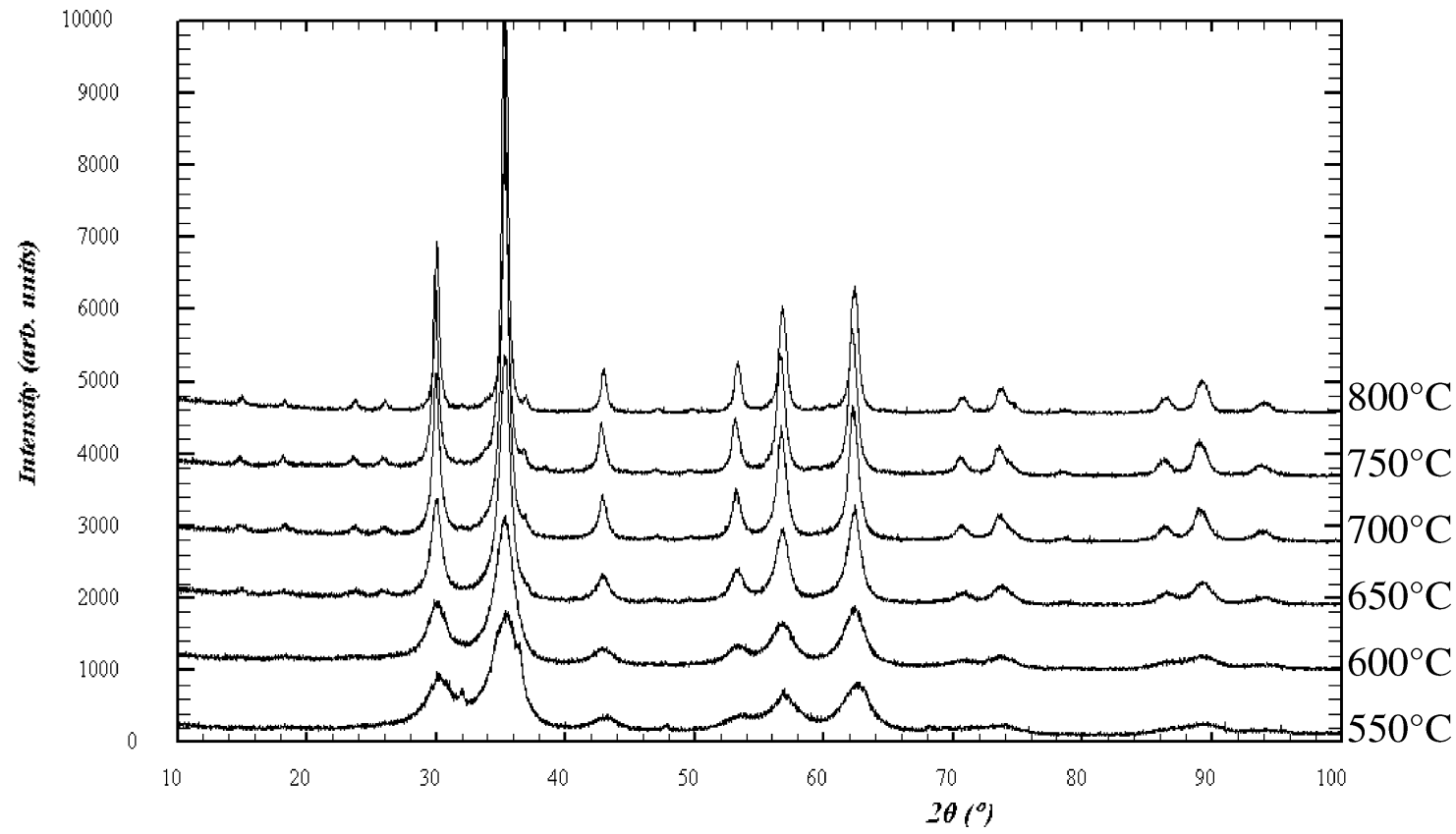

Figure 3. XRD patterns of "ZnTiON" oxynitrides powder.

diffraction data of the Ti@ZnO solid gel obtained after removing the alcohol show amorphous structure (Figure 1).

This amorphous structure can be explain by the fact that $\mathrm{Ti}^{4+}$ tetraisopropoxide (i) partly decomposes the $\mathrm{ZnO}$ nanocrystals (this has been confirmed by XRD in this work and in complementary UV - vis absorption and DLS measurements in our previous work ${ }^{10}$ ); (ii) forms itself into amorphous compounds at room temperature. In fact, XRD data reveal that the decomposition of $\mathrm{ZnO}$ nanoparticles is dependent on the amount of titanium tetraisopropoxide added into the $\mathrm{ZnO}$ nanocolloids. 149 In Figure 1, the X-ray patterns of two different $\mathrm{Zn} / \mathrm{Ti}$ ratios are 150 represented. We notice that the peaks of $\mathrm{ZnO}$ appear with the 151 ratio $\mathrm{Zn} / \mathrm{Ti}=2$, whereas they are not present for the $\mathrm{Zn} / \mathrm{Ti}=152$ 1 ratio.

In situ temperature-dependent X-ray diffraction in air shows 154 that above $150{ }^{\circ} \mathrm{C}$, for the $\mathrm{Zn} / \mathrm{Ti}=1$ ratio, peaks of zinc oxide 155 appear again (Figure 2). The binary compounds in the system 156 $\mathrm{Zn}-\mathrm{Ti}-\mathrm{O}$ can be detected only at $500{ }^{\circ} \mathrm{C}$, and no pure phase 157 


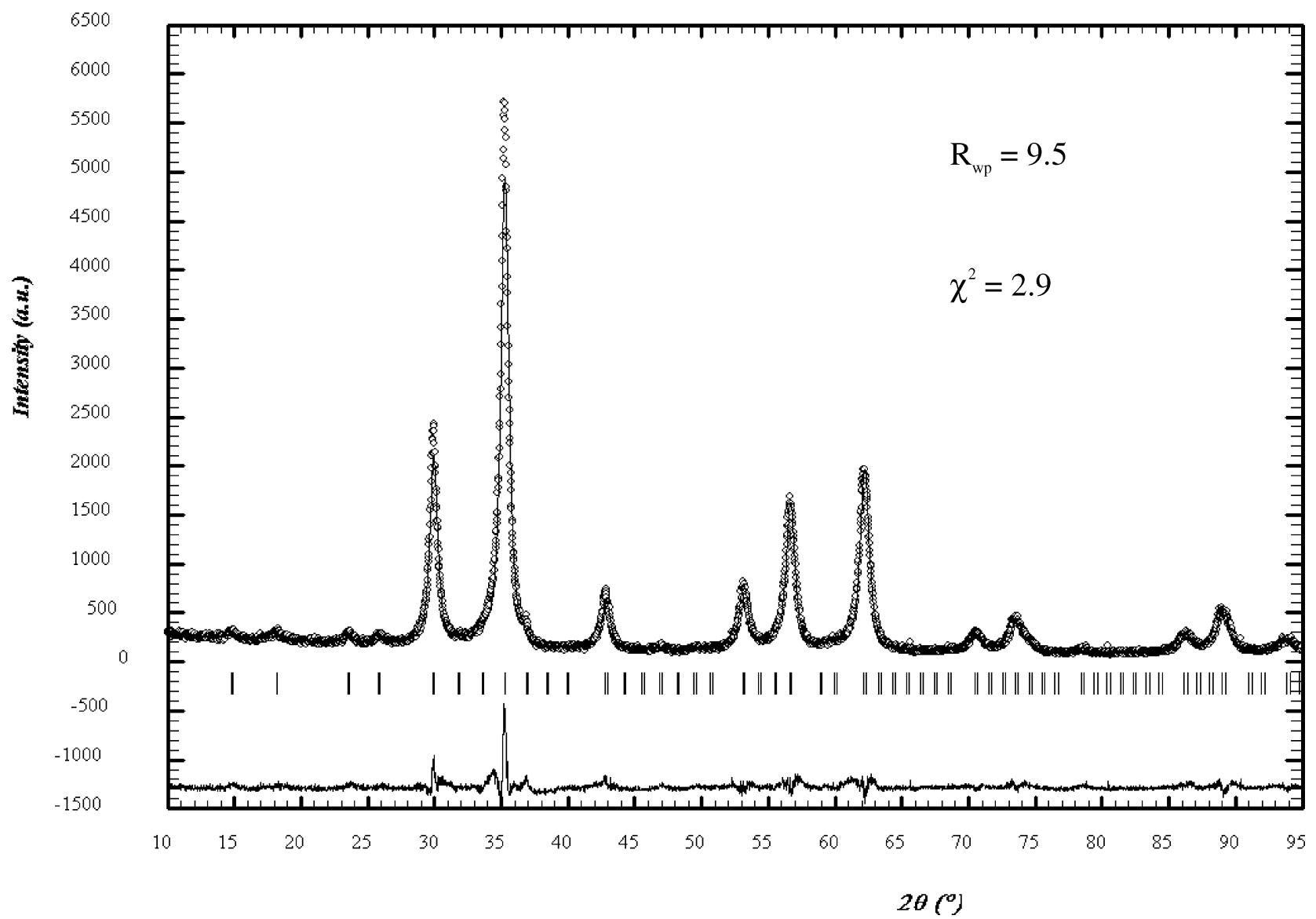

Figure 4. Observed, calculated, and difference X-ray diffraction profiles for the compound annealed at $750{ }^{\circ} \mathrm{C}$.

TABLE 1: LECO Analysis and XRD Results

\begin{tabular}{|c|c|c|c|c|c|}
\hline temp $\left({ }^{\circ} \mathrm{C}\right)$ & $\mathrm{O}(\mathrm{wt} \%)$ & $\mathrm{N}(\mathrm{wt} \%)$ & cell param $(\mathrm{nm})$ & chem composn ${ }^{a}$ & $\epsilon_{\beta(\mathrm{nm})}$ \\
\hline $600\left(\mathrm{NH}_{3}\right)$ & 27.7 & 1.8 & $8.430(1)$ & $\mathrm{Zn}_{1.33} \mathrm{Ti}_{1.33} \square_{0.33} \mathrm{O}_{3.65} \mathrm{~N}_{0.24} \square_{0.11}$ & $4.2(5)$ \\
\hline $650\left(\mathrm{NH}_{3}\right)$ & 25.9 & 2.5 & $8.430(1)$ & $\mathrm{Zn}_{1.33} \mathrm{Ti}_{1.33} \square_{0.33} \mathrm{O}_{3.49} \mathrm{~N}_{0.34} \square_{0.17}$ & $7.3(5)$ \\
\hline $700\left(\mathrm{NH}_{3}\right)$ & 24.9 & 3.0 & $8.441(1)$ & & $11.0(5)$ \\
\hline $750\left(\mathrm{NH}_{3}\right)$ & 23.8 & 3.6 & $8.441(1)$ & & $14.3(5)$ \\
\hline $800\left(\mathrm{NH}_{3}\right)$ & 25.8 & 2.5 & $8.438(1)$ & & $15.4(5)$ \\
\hline
\end{tabular}

${ }^{a}$ Taking the density into account. $\square$ represents vacancy.

could be prepared in air until $600{ }^{\circ} \mathrm{C}$. The presence of $\mathrm{ZnTiO}_{3}$ (JCPDS card $\mathrm{n}^{\circ}$ 26-1500) and $\mathrm{Zn}_{2} \mathrm{Ti}_{3} \mathrm{O}_{8}$ phases as impurity agrees with the $\mathrm{Zn}-\mathrm{Ti}-\mathrm{O}$ phase diagram. ${ }^{11} \mathrm{X}$-ray diffraction under ammonia atmosphere with our laboratory apparatus was not possible because of the high activity of ammonia gas. Only pure phases were prepared from annealed solid-gel (i) at 400 ${ }^{\circ} \mathrm{C}$ in air and (ii) using ammonia atmosphere with a temperature higher than $550{ }^{\circ} \mathrm{C}$ (Figure 3).

Analysis of the room-temperature X-ray powder diffraction data indicates that "ZnTiON" compounds annealed between 600 and $750{ }^{\circ} \mathrm{C}$ are isostructural with a cations deficient spinel type structure such as $\mathrm{Zn}_{2} \mathrm{Ti}_{3} \mathrm{O}_{8}(a=8.390 \AA) .{ }^{13}$ The observed XRD patterns were refined using the Le Bail method. The refined values of the lattice parameters and the average apparent crystallite size $\left(\epsilon_{\mathrm{b}}\right)$, extracted from the line profile fit are given in Table 1.

The observed, calculated, and difference X-ray diffraction profiles for the compound annealed at $750{ }^{\circ} \mathrm{C}$ are shown as examples in Figure 4. Classically, $F d \overline{3} m$ is used as the space group for spinel type structure, but the defect spinel that exhibits ordered cation vacancies should be indexed with $P 4_{1} 32 .{ }^{12,13}$ This ordering leads to a space group with lower symmetry. The evaluated $\epsilon_{\beta}$ were estimated within a range between 4.2 and
$15.4 \mathrm{~nm}$, which is in good agreement with the powder SEM 181 images (Figure 5).

As expected, the $\epsilon_{\beta}$ is increasing with the annealing temperature. These results agree with high-resolution transmission electron microscopy (HRTEM) and XRD data on thin film reported in ref 2. In fact, our previously obtained HRTEM images of the films have shown a broad scale of differently sized nanodomains ranging between 1 and $9 \mathrm{~nm}$, the $\epsilon_{\beta}$ increasing also with the annealing temperature. This point has been confirmed by the SEM images (Figure 5) of the powder.

Above the dissociation temperature of ammonia, the optical transmission spectra are progressively red-shifted with increasing nitriding temperature. As observed in Figure 6, the progressive $\mathrm{N}^{3-} / \mathrm{O}^{2-}$ anionic substitution gives the possibility to tune the absorption edge position by varying the nitridation temperature. This red shift is directly related to the nitrogen content determined by LECO apparatus (Table 1) and coincides with the observation generally made for micrometer-sized nitrided oxide powders. ${ }^{14}$

In our previous papers, ${ }^{2,10}$ the presence of $\mathrm{N}^{3-}$ was confirmed on colored thin film by XPS techniques (the N K-edge located at $396.1 \mathrm{eV}$ proves the presence of oxynitrides). In addition, when raising the nitridation temperature, a new $\mathrm{Ti}(2)$ component 


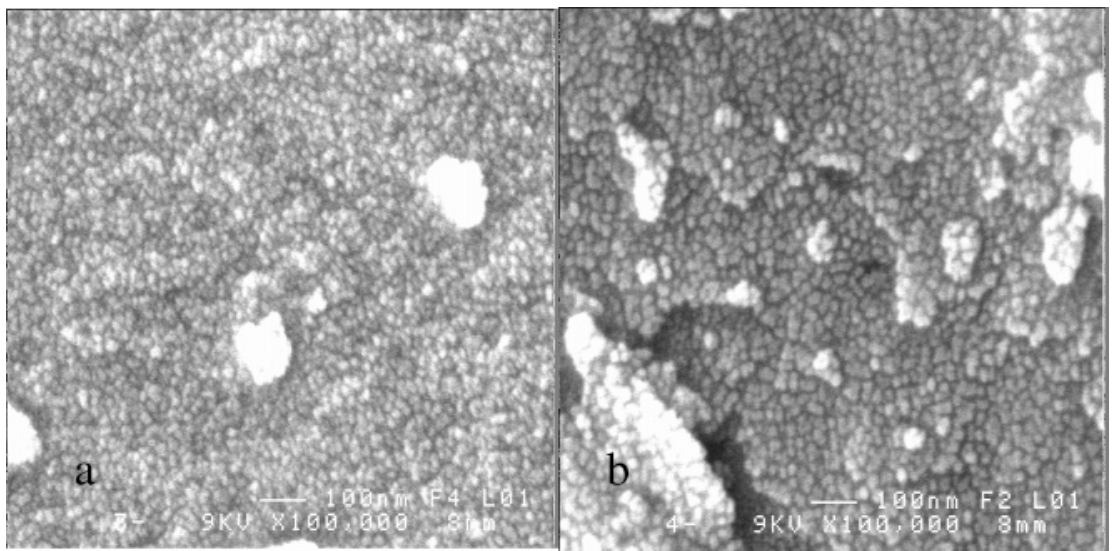

Figure 5. SEM images of nanosized powder annealed at $400{ }^{\circ} \mathrm{C}$ under air (a) and $700{ }^{\circ} \mathrm{C}$ under ammonia flow (b).

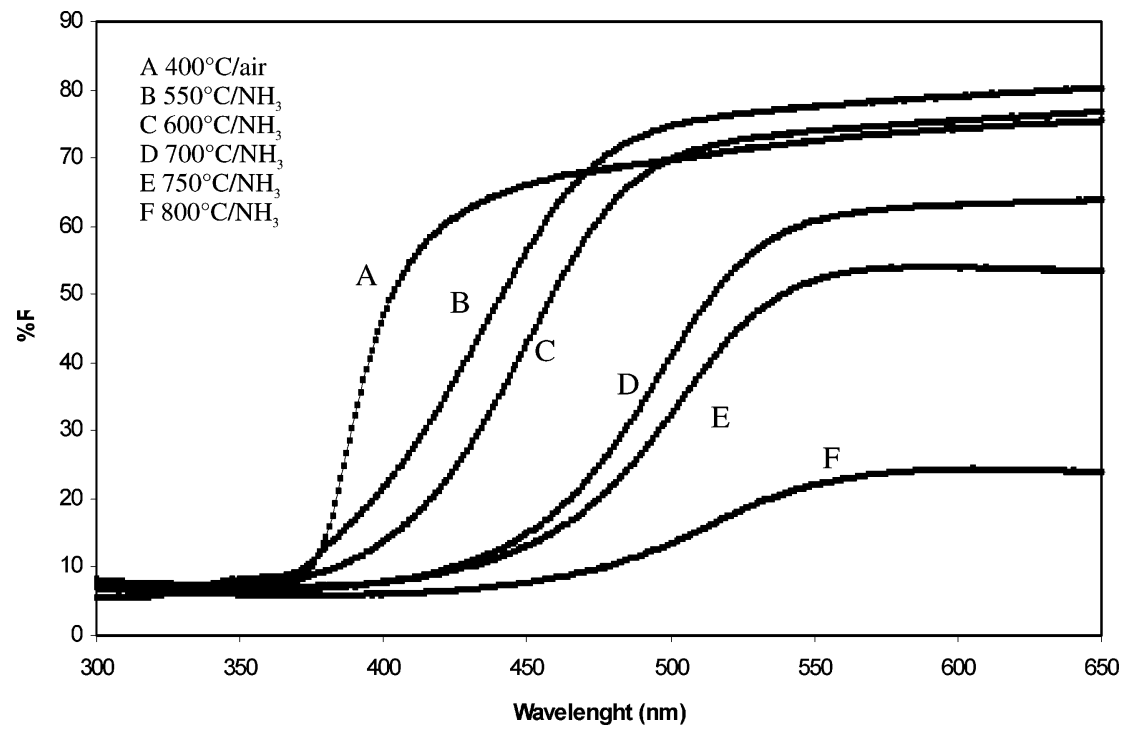

Figure 6. Changes in the optical transmission spectra of "ZnTiON" nanosized powders with increasing nitriding temperature.

appears at the low-energy side of the XPS-Ti spectra which is related to the nitrogen incorporation. This new component was attributed to $\mathrm{Ti}-\mathrm{N}$ bounds. ${ }^{2,10}$ In the present case of nanosized powders, preliminary XPS analysis of $\mathrm{Zn}$ and Ti reveals that after $1 \mathrm{~h}$ treatment under ammonia at 600 and $650{ }^{\circ} \mathrm{C}$ the $\mathrm{Zn} /$ Ti remains close to 1 . Using all these results, a chemical formula could be proposed for the compounds annealed at 600 and 650 ${ }^{\circ} \mathrm{C}$ (Table 1), keeping the $\mathrm{Zn} / \mathrm{Ti}$ ratio equal to 1 . As an example, the chemical formula for the compound annealed at $650{ }^{\circ} \mathrm{C}$ could be written as $\mathrm{Zn}_{1.33} \mathrm{Ti}_{1.33} \square_{0.33} \mathrm{O}_{3.49} \mathrm{~N}_{0.34} \square_{0.17}$ following ref 15. For higher temperature, analysis is in progress. Nevertheless we could expect some nonstable phases because LECO analyses show that, for temperatures higher than $800{ }^{\circ} \mathrm{C}$, the nitrogen content decreases. The powder slightly becomes green-yellow, indicating a metal reduction process. ${ }^{16}$ This phenomenon has been already observed for micrometer-sized powder oxynitridesthe nitrogen content reaches a maximum when the temperature is increased and then it decreases due to the volatilization or the reduction of metal. ${ }^{15}$ As a result, the domain of existence of "ZnTiON" oxynitrides is limited in temperature (between 550 and $800{ }^{\circ} \mathrm{C}$ ). Moreover, thermogravimetric measurement (temperature rate, $10^{\circ} \mathrm{C} / \mathrm{min}$ ) shows that these oxynitrides are stable in air until $430{ }^{\circ} \mathrm{C}$; a further increase of the weight indicates an oxidation process. Nevertheless, we notice that, thanks to our nanocolloid approach, pure oxynitride phases were obtained only after $1 \mathrm{~h}$ (only $15 \mathrm{~min}$ for $1 \mu \mathrm{m}$ thick film) of annealing time under ammonia flow, whereas the classical nitridation process usually takes several hours. ${ }^{15}$

\section{Conclusion}

We are able to prepare new spinel oxynitride compounds with tunable band gap from white to yellow colors. A chemical formula is proposed for the compounds annealed at 600 or 650 ${ }^{\circ} \mathrm{C}$, and it could be written as " $\mathrm{Zn}_{1.33} \mathrm{Ti}_{1.33} \mathrm{O}_{4-3 y} \mathrm{~N}_{2 y}$ ". These compounds present promising semiconducting properties for potential gas sensing or sunscreen applications.

Acknowledgment. The authors thank N. Pontais for providing LECO analysis, F. Tessier for X-ray measurements facilities, Prof. Marchand for helpful discussion, and M. J. Le Lannic for supplying the SEM images.

\section{References and Notes}

(1) Klabunde, K. J. Nanoscale Materials in Chemistry; Wiley VCH: New York, 2001.

(2) Grasset, F.; Starukh, G.; Spanhel, L.; Ababou-Girard, S.; Su, D.; Klein, A. Adv. Mater. 2005, 17 (3), 294. 65. Electrochem. Soc. 1998, 145, 3632.

(5) Marchand, R. Laurent, Y · Guyader, J.; L'Haridon, P . Verdier, P. 252 J. Eur. Ceram. Soc. 1991, 8, 197. 
F J. Phys. Chem. C

PAGE EST: 5.1

(6) Spanhel, L.; Starukh, G.; Ababou-Girard, S.; Grasset, F. Proceedings of 17th Workshop on Quantum Solar Energy Conversion (QUANTSOL 2005); Salzburg, Östrerreich, 2005.

(7) Lu, D.; Takata, T.; Saito, N.; Inoue, Y.; Domen, K. Nature 2006, 440,295

(8) Li, D.; Ohashi, N.; Hishita, S.; Kolodiazhnyi, T.; Haneda, H. J. Solid State Chem. 2005, 178 (11), 3293.

(9) Audebrand, N.; Auffrédic, J. P.; Louër, D. Chem. Mater. 1998, 10,2540 .

(10) Grasset, F.; Spanhel, L.; Ababou-Girard, S. Superlattices Microstruct. 2005, 38 (4-6), 300.
Grasset et al.

(11) Yang, J.; Swisher, H. Mater. Charact. 1996, 37, 156.

(12) Tomas, A.; Laruelle, P.; Dormann, J. L.; Nogues, M. Acta 266 Crystallogr. 1983, C39, 1615.

(13) Kim, H. T.; Kim, Y.; Valant, M.; Suvorov, D. J. Am. Ceram. Soc. 268 2001, 84 (5), 1081.

(14) Diot, N.; Larcher, O.; Marchand, R.; Kempf, J. Y.; Macaudière, P. 270 J. Alloys Compd. 2001, 45, 323. Solid State Chem. 1995, 119, 304.

(16) Orhan, E.; Tessier, F.; Marchand, R. Solid State Sci. 2002, 4, 1071.274 